\title{
EXAMINING BANKING PRODUCTIVITY DRIVERS IN MENA BANKS AFTER FINANCIAL LIBERALISATION IN 1990s
}

\author{
Hatem Elfeituri *
}

\author{
* Royal Docks School of Business and Law, University of East London, UK; University of Benghazi (Garyounis), Benghazi, Libya \\ Contact details: University of East London, Stratford campus Water Lane, London, E15 4LZ, UK
}

\begin{abstract}
OPEN ACCESS
How to cite this paper: Elfeituri, $\mathrm{H}$. (2019). Examining banking productivity drivers in MENA banks after financial liberalisation in 1990s. Journal of Governance \& Regulation, 8(1), 59-74. http://doi.org/10.22495/jgr_v8_il_p5

Copyright $\odot 2019$ The Authors

This work is licensed under a Creative Commons Attribution 4.0 International License (CC BY 4.0).

https://creativecommons.org/licenses/by/ $\underline{4.0 /}$

ISSN Print: 2220-9352

ISSN Online: $2306-6784$

Received: 20.01 .2019

Accepted: 06.03.2019

JEL Classification: G21, F30, G20

DOI: $10.22495 /$ jgr_v8_i1_p5
\end{abstract}

\begin{abstract}
The paper investigates whether deregulation and economic reforms have transformed the MENA banking sector into a more productive and efficient sector. This is the first study to cover a large sample of 11 MENA countries for an extended and recent period (1999-2012). Initially, this paper estimates the productivity and efficiency of MENA commercial banks using Malmquist DEA to estimate productivity (TFP), technological and technical efficiency, and scale efficiency change in order to investigate to what extent banking productivity in MENA economies has improved during the study period. Then, Tobit model is employed to examine the impact of bank and macroeconomic variables on the total factor productivity of MENA commercial banks. The obtained MPI results suggest that commercial banks operating in the Gulf countries have exhibited productivity progress mostly due to the technological progress rather than efficiency change. Results also suggest that expenses preference behaviour would help banks to enhance their productivity in the examined period and MENA countries. Whilst banking productivity is improved by financial reforms and technological progress, such findings overall do not indicate that foreign participation or state ownership lead to enhance productivity of banks, whilst suggesting that a number of sound policies should be implemented taking into account the characteristics of banking sector in MENA countries.
\end{abstract}

Keywords: DEA, Productivity, Efficiency, Liberalisation, MENA

\section{INTRODUCTION}

In the absence of significant role of efficient and well-developed capital market, the banking sector in MENA region plays a leading role in the economic development via providing funds to private and public sectors investments and by financing government deficits. Whilst also engaged in major economic reforms, which were required by the World Trade Organisation (WTO), to which these countries either belong or plan to join ${ }^{1}$. It is argued that these reforms are fundamental parameters for the performance of national financial system, and the development of the economy in general (Gattoufi et al., 2009). During the last three decades, MENA economies have been witnessed major developments in terms of liberalisation of national economy, elimination of either capital or ownership barriers, transferring the control of ownership of large shares

${ }^{1}$ All the countries which this study examines are full members of the WTO of the banking sector from the state to private local investors and to foreign investors (Turk-Ariss, 2009; Farazi et al., 2011; Hassan et al., 2012). The increasing number of bank failures in the 1980s and liberalisation of the banking industry in 1990s resulted in increasing academic interest in the examination of banking productivity and efficiency (Beger \& Humphry, 1997; Jaffry et al., 2007; Sufian \& Habibullah, 2013). The productivity and source of productivity for commercial banks are highly important since the existence of productive and efficient commercial banks contributes in lowering operational costs, enhancing profitability which in turns will be reflected on the stability of the financial sector and improves the overall economy and growth. Economic liberalisation and financial reforms may contribute in improving total factor productivity of banks in terms of technological change and efficiency change. In this matter, the amount to which financial institutions such as banks are capable to achieve the best allocation of funds is 
one of concerns raised by policymakers and regulators in MENA countries.

In this context, the importance and contribution of this paper are threefold. Firstly, investigating productivity and its sources and determinants of MENA banks is crucial not only in terms of policy implications to optimally structure the banking system of these countries but, most importantly, for the efficient allocation of funds and sustainable development of these regional economies in the long run. In particular, MENA region economies have been witnessing an unprecedented transformation from being solely petroleum producers to having diversified economies (Market based-economy). To succeed, this transformation requires an efficient institutions, something which, in other economies, is traditionally performed by both capital markets and banking sector. But, the fact is the capital markets in MENA economies are neither efficient nor well-developed, so banking institutions almost monopolise the role of financial intermediation. Thus, the existence of a well-functioned banking sector is crucial, not only for the development of the financial sector in these countries, and the optimal allocation of funds but for the future of these economies as a whole. Additionally, the productive and efficient banks would contribute in reaching cost efficiency and improving performance and profitability which in turns leads to maintain the stability and the overall economic productivity and growth of a country. The role of state and foreign ownership in the banking system of the examined countries had not been adequately assessed in past studies. To the best of my knowledge, this is the first study in MENA region to cover a large sample of 11 MENA countries for an extended and recent period (14 years) using Data Envelopment Analysis (DEA) approach and filling a significant gap in research using this approach for MENA economies (Ramanathan, 2006; Ramanathan 2007; Gattoufi et al., 2008; Gattoufi et al., 2009; Ben Naceur et al., 2009; Al Hammadi, 2013). Secondly, findings of this paper would help to draw, for the first time, reliable conclusions about how ownership, macroeconomic and bank-specific variables affect the total factor productivity in MENA banks after the liberalisation of the national economy. This paper is also the first in MENA that examines if state and foreign ownership contributed to an increase in productivity of banks using Tobit model. Moreover, results of the Tobit model contribute by evaluating the impact of, bank-specific variables, macroeconomic and bank ownership, year effects for financial liberalisation on productivity of MENA banks. These findings can be helpful in forming government policies intended to facilitate optimum foreign participation in a way which contributes to improve performance of banks and promote the competitive environment in MENA economies.

This paper is structured as follows: Section 2 reviews past literature and generates hypotheses that are examined in this study. Section 3 presents the methodology and model used, while Section 4 introduces the empirical results of DEA analysis. The empirical findings of Tobit regression analysis are discussed in Section 5 and finally, implications are undertaken in Section 6.

\section{DATA ENVELOPMENT ANALYSIS (DEA) LITERATURE AND HYPOTHESES DEVELOPMENT}

Berger and Humphrey (1997) outlined that there are two major approaches for measuring efficiency: the parametric approach and nonparametric approach. In general, the parametric approach specifies a functional form for the cost, revenue, profit or production relationship among inputs, outputs and other factors such as the environment. The most common method used in the parametric approach is Stochastic Frontier Approach (SFA). In contrast, the best-known nonparametric approach is Data Envelopment Analysis (DEA), which is a linear programming formulation that outlines a nonparametric relationship between multiple outputs and multiple inputs used, or it can be defined as a mathematical model for making production frontiers and measuring the relative efficiency of these frontiers carrying no random error in constructing the frontier (Humphrey \& Beger, 1997).

However, in finance and banking literature, there are several different techniques used to estimate productivity change and technical efficiencies such as the Fisher index, the Tornqvist index and the Malmquist index. The most common method for measuring productivity is (MPI) Malmquist Productivity Index (Färe et al., 1994). Studies on productivity using MPI indices have been carried out in a number of different industries in well-developed and developing economies (Isik \& Hassan, 2003; Jaffry et al., 2007; Gattoufi et al., 2009; Habibullah, 2013). Achieving productivity and efficiency of banks is matter for different parties; it is very essential to obtaining appropriate resource allocations, which in turns benefits the whole society and ensuring better innovations, enhancing profitability, and creating suitable environment conditions of competition as well as safeguarding the stability of the financial sector. Nevertheless, the evidence of the effect of liberalisation on productivity of financial institutions and other industries are mixed. For instance, in well-developed economies, Färe et al. (1994) analysed productivity growth in seventeen OECD countries and suggested that US productivity growth is relatively higher than average due to technological progress. However, studies in emerging and developing markets have been looked at investigating banking productivity in Malaysia, India, China, Turkey and MENA countries. In this regard, Isik and Hassan (2003) employed DEA using MPI to examine how financial reforms affect total factor productivity of Turkish banks over the period 1981-1990. Findings imply that performance of all types of banks exhibited major improvements after liberalisation and the productivity was mainly driven by increasing in technical efficiency attributed to improvements of management practices rather than technological progress. In the same context, in Malaysia, Krishnasamy et al. (2003) examined the nature and extent of the productivity change of ten commercial banks operating in Malaysia for the period 2000-2001, finding that the total factor productivity increased, but two banks which showed a decline in productivity. Overall, the total factor productivity growth for Malaysian banks was attributed to technological progress rather than technical efficiency change reflecting investment in technology. On the other hand, Sufian and 
Habibullah (2013) provided empirical evidence about the impact of economic globalisation on total factor productivity in Malaysian banks during the period 1998-2007. The results of MPI showed that banks have experienced productivity growth, mainly due to efficiency increases rather than progress in technology. However, in India, Pakistan and Bangladesh, there have been a number of studies focusing on the impact of deregulation on banking sector Jaffry et al. (2007) aimed at estimating changes in productivity and efficiency level within banking sectors of the Indian sub-continent: specifically India, Pakistan and Bangladesh for the period 1993-2001. It was observed that India and Bangladesh experienced an immediate and sustained increase in technical efficiency, while Pakistan suffered from a decline in efficiency over the years of the examined period.

In MENA economies, the banking sector is committed to sustainable development and is engaged in major economic reforms as required for the adhesion to the World Trade Organisation (WTO). In addition, as previously mentioned at the beginning of this paper, due to the absence of efficient and well-developed stock exchange markets, the banking sector in this region still plays a leading role in the intermediation process between users and suppliers of funds. In this respect, Ramanathan (2006) employed MPI to assess the comparative performance of selected MENA banks over the period 1980-1999, findings telling that technological progress have contributed to improvements of total factor productivity. In another study, Ramanathan (2007) also suggested that banks operating in four GCC countries (Bahrain, Kuwait, Saudi Arabia and UAE) experienced productivity growth during 2000-2004. The selected banks in Bahrain have revealed the highest productivity improvements during the examined period; whereas, the selected banks in Qatar have shown the highest decline in the productivity.

In the same matter, the impact of mergers and acquisitions on the efficiency of banks in MENA countries is investigated by Gattoufi et al. (2008). The MPI has been utilised to analyse the evolution of efficiency over time. Results of the study exhibited the positive impact that mergers and acquisitions had on the MENA banking industry. Another study (Gattoufi et al., 2009) examined the impact which change in ownership has had on the efficiency of MENA banks. Findings show the decomposition of the MPI and the technical efficiency scores, one can indicate that the impact of change in ownership has affected in the scale efficiency rather than in pure technical efficiency. Whilst, Ben Naceur et al. (2009) investigate the impact of deregulation policies on the performance of selected MENA banks over the period 1993-2006. Findings indicate that Morocco and Tunisia have demonstrated efficient banking systems when compared to others.

The impact of the 2007-2008 financial crisis on Islamic Financial Institutions (IFIs) in Gulf Countries Council (GCC) is examined by Al Hammadi (2013). The results of MPI stated, that both GCC and nonGCC IFIs revealed a progress in efficiency during the study period, whereas scale efficiency was the least source of efficiency. Overall, based on the above arguments, the first hypothesis for this paper is generated as follows:
Hypothesis 1 ( $H$ ): Banking productivity in MENA economies has improved during the examined period. Additionally, this paper also provides empirical evidence on the impact of financial liberalisation using year effects and determinants of total factor productivity in MENA banking economies. Therefore, in the second stage of the methodology, the Tobit model is employed to investigate whether the financial liberalisation and other variables such as size of banks, risk, market structure and macroeconomic variables have an effect on the productivity of commercial banks. In this matter, in EU market, Rezitis (2004) investigated the productivity growth and technical efficiency in the Greek banking sector using MPI. The empirical results from the Tobit model reveal that size and specialisation have had positive impacts on both pure and scale efficiency. However, in Asia, Das and Kumbhakar (2012) investigated the impact of banking deregulation on efficiency and productivity change in the Indian banking sector. Empirical findings suggest that banks experienced a growth in their efficiency (from 61\% in 1996 to $72 \%$ in 2005) during the post-deregulation period.

In respect to the market I examine (MENA banking sector), previous studies (Isik \& Hassan, 2003; Krishnasamy et al., 2003; Howcroft \& Ataullah, 2006; Ben Naceur et al., 2009; Das \& Kumbhakar, 2012) suggested that performance of all types of banks exhibited major improvements after liberalisation, and such improvements were attributed to improvements of management practices, more investment in technology and positive impact of mergers and acquisitions on the banking sector. Ben Naceur et al. (2009) examine the impact of deregulation policies on the performance of selected MENA banks over the period 1993-2006, employing Tobit model to examine the impact of institutional, financial and bank characteristics variables on banks efficiency. The findings present a robust relationship between some environmental measures and cost efficiency, implying that well capitalised and liquid banks recorded higher efficiency scores. Results also revealed that banking sector development, measured by credit provided by banks to the private sector in a low regulated business, is more likely to reduce bank efficiency. Further, highly concentrated banking sectors tend to decrease banks' efficiency and financial reforms enhance efficiency of banks in MENA, with Egyptian banks exhibiting the lowest efficiency in the region. Such literature and past studies in different emerging and developing economies led to formulate the second hypothesis of this study as follows:

Hypothesis $2\left(H_{2}\right):$ The productivity of banks in MENA economies is influenced by a bank specific variables, market structure and macroeconomic variables.

The empirical findings of this paper are interesting from the policy makers' perception and bank management. They will be more motivated to find what factors to achieve the optimal utilisation of capacities and ensuring that they are being optimised over the production of banking products and services. Taking such factors into account, the empirical results of this paper will demonstrate considerable policy implications. 


\section{THE DATA ENVELOPMENT ANALYSIS (DEA) METHODOLOGY}

The DEA approach was suggested by Charnes et al. (1978) in response to the needs for satisfactory procedures to measure the relative efficiency of multiple inputs-outputs production units. The DEA mainly aims at providing a methodology to create a set of comparable decision making units (DMUs) to identify those which have best practice and efficient frontier. The methodology of this paper encompasses measurements of the productivity and efficiency performance of MENA commercial banks for the period 1999-2012.

\subsection{Specification of DEA inputs and outputs}

Using DEA requires specifying inputs and outputs to estimate productivity and efficiency for banks (Berger \& Humphrey, 1997). In the banking literature, there are two different perspectives for using DEA (intermediation approach and production approach). With respect to intermediation approach, banks are deemed to be financial intermediates that aim at converting financial resources between surplus firms to deficit firms. Based on this view, outputs can be loans and deposits, whereas inputs may comprise labour, fixed assets, and loanable funds. On the other hand, the production approach considers banks to be producers of financial services for their customers that seek to execute transactions on deposits accounts and process loans. Therefore, outputs under this view may consist of interest income and non-interest income, while, inputs can be physical capital and the number of employees (Luo, 2003). Accordingly, MENA banks are treated as intermediaries between savers and borrowers, producing three outputs namely total loans (Y1), interest income (Y2) and non-interest income (Y3), by using total deposits (X1), total fixed assets (X2), interest expense (X3) and non-interest expense (X4) as inputs, see Table 1.

Table 1. Definition and explanation of inputs and outputs variables

\begin{tabular}{|c|c|}
\hline Variable & Definition \\
\hline \multicolumn{2}{|r|}{ Outputs: } \\
\hline Y1 & Total loans \\
\hline Y2 & Interest income \\
\hline Y3 & Non-interest income \\
\hline \multicolumn{2}{|r|}{ Inputs: } \\
\hline $\mathrm{X} 1$ & Total deposits \\
\hline $\mathrm{X} 2$ & Total fixed assets \\
\hline $\mathrm{X} 3$ & Total interest expense \\
\hline $\mathrm{X} 4$ & Total non-interest expense \\
\hline
\end{tabular}

\subsection{DEA using the Malmquist Productivity Index (MPI)}

Examining the productivity and efficiency of MENA banks would require using Malmquist DEA to estimate total factor productivity change (TFPCH), technical efficiency in order to investigate the first hypothesis. This index was primarily developed by Malmquist in 1953. The Malmquist productivity index (MPI) utilises panel data to compute indices of total factor productivity change and scale efficiency change (Krishnasamy et al., 2003; Coelli, 1996). Following Färe et al. (1994) and Jaffry et al. (2007) the output orientation is more suitable given the objectives of developing economies' banking industry.

In order to run the MPI, distance functions have to be allocated regarding the two different periods (times).

Färe et al. (1994) define the MPI as:

$$
M^{t}\left(x_{j}^{t+1}, y_{j}^{t+1}\right)=\frac{D^{t}\left(x_{j}^{t+1}, y_{j}^{t+1}\right)}{D^{t}\left(x_{j}^{t}, y_{j}^{t}\right)}
$$

or

A measure of productivity change (TFPCH) is provided by equation (1); it grows or declines due to changes in technical efficiency (Eff) and technological change (Tech) and decomposition of the technical efficiency index are pure technical efficiency (PureEff) and scale efficiency(scale).

To avoid selecting an arbitrary benchmark, two continuous MPIs are integrated into a single index by calculating the geometric mean and then multiplicatively decomposed into sub-indices measuring changes in technical efficiency and technology as follows (Färe et al., 1989; Färe et al., 1994).

$$
\begin{gathered}
\Delta E f f^{t, t+1}=\frac{D_{c}^{t+1}\left(x_{j}^{t+1}, y_{j}^{t+1}\right)}{D_{c}^{t}\left(x_{j}^{t}, y_{j}^{t}\right)} \\
\Delta \operatorname{Tech}^{t, t+1}=\sqrt{\frac{D_{c}^{t}\left(x_{j}^{t+1}, y_{j}^{t+1}\right)}{D_{c}^{t+1}\left(x_{j}^{t+1}, y_{j}^{t+1}\right)} \times \frac{D_{c}^{t}\left(x_{j}^{t}, y_{j}^{t}\right)}{D^{t+1}\left(x_{j}^{t}, y_{j}^{t}\right)}}
\end{gathered}
$$

Equation (2) is an index of technical efficiency change between period $t$ and $t+1$, as it measures whether bank $j$ witnessed improvements or went away from best practices for the time period. The value of $\Delta E f f^{t, t+1}$ can be greater than, equal to, or less than based on whether the relative efficiency of bank $j$ improved, unchanged, or decreased respectively through the period. Whereas, $\Delta T e c h^{t, t+1}$ in equation (3) reflects technological change as it provides the geometric mean of two ratios. A value of $\Delta T e c h^{t, t+1}$ greater than 1 indicates progress, equal to 1 refers that there is no change and less than one indicates decline or regress in technology for the period $t$ and $t+1$.

$$
M^{t, t+1}=\Delta E f f^{t, t+1} \times \Delta T e c h^{t, t+1}
$$

Therefore, changes in productivity are the decomposition of changes in efficiency and technology as $M^{t, t+1}$ can be greater than, equal to, or less than 1 reflecting progress, no change, regress in total factor productivity between periods $t$ and $t+1$. Regarding the technical efficiency, the $\Delta E f f^{t, t+1}$ index is disaggregated into its mutually comprehensive components of pure technical efficiency change $\Delta P$ ureE $f f^{t, t+1}$ computed relative to the variable returns to scale (VRS) technology as well as a component of scale efficiency change $\Delta s c a l e^{t, t+1}$ to calculate changes in the deviation between the VRS and CRS technologies as:

$$
\Delta E f f^{t, t+1}=\Delta \text { PureEff } f^{t, t+1} \times \Delta s c a l e^{t, t+1}
$$




$$
\begin{gathered}
\Delta \text { PureEff } f^{t, t+1}=\frac{D_{v}^{t+1}\left(x_{j}^{t+1}, y_{j}^{t+1}\right)}{D_{v}^{t}\left(x_{j}^{t}, y_{j}^{t}\right)} \\
\Delta \text { scale }^{t, t+1}=\frac{D_{c}^{t+1}\left(x_{j}^{t+1}, y_{j}^{t+1}\right) / D_{v}^{t+1}\left(x_{j}^{t+1}, y_{j}^{t+1}\right)}{D_{c}^{t}\left(x_{j}^{t}, y_{j}^{t}\right) / D_{v}^{t}\left(x_{j}^{t}, y_{j}^{t}\right)}
\end{gathered}
$$

The subscripts $\mathrm{v}$ and $\mathrm{c}$ represent VRS and CRS technologies. When $\Delta$ PureEff $f^{t, t+1}>1$ implies that there is an increase in pure technical efficiency, while $\Delta$ PureEff $f^{t, t+1}<1$ indicates decline or regress and $\Delta$ PureEff $f^{t, t+1}=1$ shows that there is no change in pure technical efficiency. Likewise, $\Delta$ scale $^{t, t+1}>1$ suggests that there is an increase in the most efficient scale and hence, scale efficiency is improving, whereas $\Delta$ scale $e^{t, t+1}<1$ indicates a decline and $\Delta$ scale $^{t, t+1}=1$ implies no change in scale efficiency.

\subsection{The determinants of banking productivity}

In the second stage of this methodology, this paper uses the Tobit regression model to test Hypothesis 2 to obtain the impacts of bank-specific variables, macroeconomic variables and year and country effects on the total factor productivity of MENA banks. Since total factor productivity indices obtained from the DEA, in this case, they are truncated data for which ordinary least squares $(O L S)$ is not suitable for such purpose. In this model, the dependent variable is the total factor productivity (TFPCH) which is a measure of productivity growth calculated by MPI using DEA (Färe et al., 1989; Färe et al., 1994; Rezitis, 2004). Table 2 summarises the definitions of variables used in investigating the determinants of productivity of MENA banks.

\begin{tabular}{|c|c|}
\hline Variable & Descriptive \\
\hline TFPCH & Total factor productivity change index derived from Malmquist Index (MPI) \\
\hline SIZE & $\begin{array}{l}\text { Log of total assets represents bank size including earning assets }+ \text { cash and due from banks }+ \text { foreclosed real } \\
\text { estate + fixed assets + goodwill }\end{array}$ \\
\hline EQAS & $\begin{array}{l}\text { Equity to total assets. This variable to measure capital adequacy computed as equity to total assets. High capital- } \\
\text { asset ratios indicate low leverage and therefore lower risks }\end{array}$ \\
\hline COST & The cost to income ratio \\
\hline LOANAST & $\begin{array}{l}\text { This is a measure of risk computed as loans to average total assets. Higher ratios imply lower liquidity and more } \\
\text { interest revenues because of higher risks. However, loans also have higher operational costs due to monitoring, } \\
\text { originating and serving of loans }\end{array}$ \\
\hline INF & The real inflation rate \\
\hline GDPGR & The real gross domestic product (GDP) growth \\
\hline $\mathrm{CR}$ & $\begin{array}{l}\text { The Herfindahl- Hirschman Index (HHI). The HHI is a measure of market concentration within the industry and is } \\
\text { used as indicator of the market structure in MENA banking sector }\end{array}$ \\
\hline MS & A measure calculated by dividing the assets of each bank with the assets of all banks operating in a country \\
\hline FORE & Dummy variable for foreign ownership \\
\hline STATE & Dummy variable for state ownership \\
\hline COUN & Country effects \\
\hline YEAR & Year effects \\
\hline
\end{tabular}

Table 2. Definitions of variables used in assessing productivity

Source: Bankscope and IMF.

In respect to independent variables, Bank size (SIZE) is measured by using average total assets (Smirlock, 1985; Lloyd-Williams, 1994; DemirgucKunt \& Huizinga, 1999; Samad, 2008; Dietrich \& Wanzenried, 2014). The bank size variable takes into consideration differences derived by size in terms of economies of scale. Compared to smaller banks, larger banks are expected to experience economies of scale by having superior investments opportunities. The cost to income ratio (COST) is defined as operating costs (staff salaries, property costs, administrative expenditures etc.) over total generated revenues. It measures the overheads or expenses required to run a bank or to measure the effect of efficiency in managing expenditures (Pasiouras \& Kosmidou, 2007; Obamuyi, 2013; Dietrich \& Wanzenried, 2014). The key component of which wages and administrative expenses as percentage of income can provide information on variation of bank expenditures over banking system. The equity to total assets (EQAS) variable is included in this model as a measure of capital strength. In line with previous studies (Demirguc-Kunt \& Huizinga, 1999; Pasiouras \& Kosmidou, 2007; Kosimdou, 2008; Dietrich \& Wanzenried, 2014), loans over assets ratio (LOANAST) representing the loans portfolio and the coefficient of this variable is expected to be positive as more loans indicate more productivity.

In respect to macroeconomic and market structure variables, the Herfindahl-Hirschman Index
(HHI) is used to denote market concentration (CR). Whilst, the second measure to estimate the impact of market structure is the market share $(M S)$ as it takes the market share of each bank in a market measured by total assets. Given the fact that the economic condition of a country may affects the performance of banking industry, following (Demirguc-Kunt \& Huizinga, 1999; Pasiouras \& Kosmidou, 2007; Sufian, 2013; Dietrich \& Wanzenried, 2014) the gross domestic product growth (GDPGR) is considered the most commonly macroeconomic factor to measure the total economic activity within an economy. GDPGR is expected to have a positive effect on bank's productivity. Another important factor that affects both costs and revenues of banks is inflation (INF). The relationship between inflation and bank productivity depends on whether inflation is anticipated or unanticipated. With respect to anticipated inflation, banks are able to adjust interest rates which will lead to increased revenue than costs (Demirguc-Kunt \& Huizinga, 1999). Finally, to investigate whether ownership influences bank profitability, in this study I categorise a bank as state-owned bank if the government owns more than 50\%. Foreign ownership is also regarded to exhibit an impact on productivity. A bank is considered to be a foreign bank if foreigners own more than $50 \%$ of its shares are owned by foreign investors. Earlier studies (Demirguc-Kunt \& 
Huizinga, 1999; Pasiouras \& Kosmidou, 2007; Micco et al., 2007; Kosimdou, 2008; Sufian, 2013; Obamuyi, 2014; Dietrich \& Wanzenried, 2014). Finally, YEAR and COUN are used to capture the year and country effects respectively.

The following regression model (equition 8) is estimated, the total factor productivity change (TFPCH) is used as dependent variable. Whilst, for independent variables, Size represents the bank size measured by log of total assets, equity to assets ratio (EQAS) is employed to capture capital adequacy and loans to assets ratio (LOANAST) to account for bank-specific risk. The cost to income ratio (COST) is the cost management efficiency in MENA banks (Pasiouras \& Kosmidou, 2007; Kosimdou, 2008; Obamuyi, 2014; Dietrich \& Wanzenried, 2014). $C R$ is market concentration. Whilst, the second measure to estimate the impact of market share is MS.

$$
\begin{gathered}
\text { TFPCH }_{i t}=\alpha+\beta_{1} \text { Size }_{i t}+\beta_{2} E Q A S_{i t}+\beta_{3} \operatorname{COST}_{i t}+ \\
+\beta_{4} \text { LOANAST }_{i t}+\gamma_{1} I N F_{j t}+\gamma_{2} G D P G R_{j t}+\gamma_{3} C_{j t}+ \\
\quad+\gamma_{4} \text { MR }_{j t}+\text { FORE }+ \text { State }+ \text { COUN }+ \text { YEAR }
\end{gathered}
$$

The gross domestic product (GDPGR) and the inflation rate (INF) are employed to control differences in macroeconomic; whilst FORE, STAT are used in the model to investigate the effect of foreign ownership, state control as dummy variables, whilst, COUN and YEAR are employed to capture the country effects and year effects respectively on MENA banks productivity.

\section{DEA AND THE MALMQUIST INDEX (MPI) FINDINGS}

In this section, DEA is employed to calculate the distance functions of (MPI) using DEAP version. This software utilises panel data to compute indices of total factor productivity change, technological change, technical efficiency change, pure technical efficiency change and scale efficiency change.

\subsection{Empirical results of Malmquist Index in Saudi Arabia}

Estimates of MPI for commercial banks in Saudi Arabia are presented in Table 3. Given that the total factor productivity is a multiplicative compound of technical efficiency change and technological change, productivity improvements are determined by comparing the values of efficiency change and technological change indices. In other words, productivity improvement is due to results of efficiency gains (loss), technological progress

\begin{tabular}{|c|c|c|c|c|c|}
\hline Year & $\begin{array}{c}\text { Technical efficiency } \\
\text { change }{ }^{* * *}\end{array}$ & $\begin{array}{c}\text { Technological } \\
\text { change }\end{array}$ & $\begin{array}{c}\text { Pure technical } \\
\text { efficiency change }\end{array}$ & $\begin{array}{c}\text { Scale efficiency } \\
\text { change }\end{array}$ & $\begin{array}{c}\text { Total factor } \\
\text { productivity* }\end{array}$ \\
\hline 2000 & 0.979 & 0.980 & 0.995 & 0.984 & 0.959 \\
\hline 2001 & 1.017 & 1.142 & 0.993 & 1.025 & 1.161 \\
\hline 2002 & 1.017 & 1.289 & 1.011 & 1.005 & 1.310 \\
\hline 2003 & 1.009 & 1.337 & 1.003 & 1.006 & 1.349 \\
\hline 2004 & 1.000 & 1.169 & 1.000 & 1.000 & 1.169 \\
\hline 2005 & 0.990 & 1.042 & 1.000 & 0.990 & 1.032 \\
\hline 2006 & 0.999 & 1.013 & 1.000 & 0.999 & 1.012 \\
\hline 2007 & 0.994 & 0.821 & 1.000 & 0.994 & 0.816 \\
\hline 2008 & 1.013 & 0.971 & 1.000 & 1.013 & 0.984 \\
\hline 2009 & 0.989 & 1.212 & 1.000 & 0.989 & 1.199 \\
\hline 2010 & 0.976 & 1.296 & 1.000 & 0.976 & 1.264 \\
\hline 2011 & 1.020 & 0.971 & 1.000 & 1.020 & 0.990 \\
\hline 2012 & 1.000 & 0.946 & 1.000 & 1.000 & 0.946 \\
\hline Mean & 1.000 & 1.081 & 1.000 & 1.000 & 1.081 \\
\hline
\end{tabular}
(decline) or both.

Table 3. Annual means of Malmquist Indices of banks in Saudi Arabia

Table 3 shows the annual means of MPI over 14 years. There is an increase in total factor productivity for banks operating in Saudi Arabia of $8.1 \%$, suggesting that total factor productivity of the commercial banks in Saudi Arabia have regressed during the years 2000, 2007, 2008, 2011 and 2012, while years of 2001, 2002, 2003, 2004, 2005, 2006, 2009 and 2010 witnessed productivity growth. The $8.1 \%$ increase in total factor productivity in Saudi commercial banks could be due to the $8.1 \%$ increase in technological progress.The results for this country are expected and would support the hypothesis (1). It can be observed from the table that the overall rise in total factor productivity was mainly determined by technological progress rather technical efficiency. This development is related to the fact that the Saudi banking sector has a share of foreign presence in its banks bringing more investments in technological innovations.

\subsection{Empirical results of Malmquist Index in the United Arab Emirates (UAE)}

Table 4 presents the results of total factor productivity for commercial banks operating in the United Arab Emirates (UAE). The annual means of MPI are presented in Table 4 . The results indicate that over the examined period, there was annual mean increase in total factor productivity for all banks of $4.4 \%$. In more details, the commercial banks in the UAE exhibited a rise in total factor productivity during the years 2001, 2002, 2003, 2004, 2008, 2011 and 2012, telling that the overall improvement in total factor productivity was attributed to technological progress (upward shift of frontier) of $3.9 \%$. The major increase in total factor productivity was in 2011 of $68 \%$ mainly attributed to technological progress of $65.4 \%$ and then increase in technical efficiency of $1.7 \%$. In respect to annual results of technological change, results show that 
over the study period there was a technological progress for years 2001, 2002, 2003, 2008, 2011 and 2012. On the other hand, it can be seen that there is no massive development in efficiency as the annual mean of efficiency was $4 \%$ which confirms that technological change has contributed more in improving productivity of UAE banks rather than technical efficiency.

Table 4. Annual means of Malmquist Indices of banks in the United Arab Emirates

\begin{tabular}{|c|c|c|c|c|c|}
\hline Year & $\begin{array}{c}\text { Technical efficiency } \\
\text { change }\end{array}$ & $\begin{array}{c}\text { Technological } \\
\text { change }\end{array}$ & $\begin{array}{c}\text { Pure technical } \\
\text { efficiency change }\end{array}$ & $\begin{array}{c}\text { Scale efficiency } \\
\text { change }\end{array}$ & $\begin{array}{c}\text { Total factor } \\
\text { productivity }\end{array}$ \\
\hline 2000 & 0.952 & 0.961 & 0.962 & 0.990 & 0.915 \\
\hline 2001 & 1.045 & 1.029 & 1.022 & 1.023 & 1.076 \\
\hline 2002 & 1.013 & 1.365 & 1.008 & 1.004 & 1.382 \\
\hline 2003 & 0.959 & 1.201 & 0.986 & 0.972 & 1.152 \\
\hline 2004 & 1.052 & 0.999 & 1.039 & 1.012 & 1.050 \\
\hline 2005 & 0.981 & 0.889 & 0.975 & 1.006 & 0.872 \\
\hline 2006 & 0.907 & 0.970 & 0.914 & 0.993 & 0.880 \\
\hline 2007 & 1.181 & 0.731 & 1.163 & 1.016 & 0.863 \\
\hline 2008 & 0.997 & 1.189 & 1.000 & 0.997 & 1.186 \\
\hline 2009 & 1.007 & 0.803 & 1.000 & 1.007 & 0.808 \\
\hline 2010 & 0.987 & 0.942 & 0.987 & 1.000 & 0.930 \\
\hline 2011 & 1.017 & 1.654 & 1.014 & 1.004 & 1.682 \\
\hline 2012 & 0.989 & 1.089 & 1.000 & 0.989 & 1.077 \\
\hline Mean & 1.005 & 1.039 & 1.004 & 1.001 & 1.044 \\
\hline
\end{tabular}

$* *$ Technical efficiency change $=$ Pure technical efficiency $\times$ Scale efficiency change

Overall, the total productivity changes for banks in the UAE appear to be determined by technological progress rather than technical efficiency. Such results indicate that most of the banks operating in the UAE tend to be investing more in retail banking technologies such as ATMs, internet banking, and smart cards confirming the first hypothesis. Since the advent of the global business, it has become obvious for the banking industry in the UAE to pursue technological progress, leading domestic banks to take advantage of technological items brought by the foreign investment.

\subsection{Empirical results of Malmquist Index in Oman}

Results presented in Table 5 show the MPI estimates for annual means of banks in Oman. The annual total factor productivity exhibited an increase of $14.3 \%$, which seems to suggest that commercial banks in Oman witnessed improvements in total factor productivity during years 2000, 2001, 2002, 2003, 2004, 2007, 2008 and 2012. The 14.3\% increase in total factor productivity of the Omani commercial banking sector is related as shown to $14.2 \%$ increase in technological change (technological progress), which reflects that commercial banks have benefited from expending their capital investments on technology. Such figures reflect that Omani banks have invested more in better capabilities systems and equipment due to the financial liberalisation and financial reforms that have been taken place in that period.

On the other hand, the annual efficiency of banks seems to be increased only by $1 \%$ as the highest increase of technical efficiency was 33\% in 2009. The improvement of efficiency as it is shown in the table is mainly due to scale efficiency rather than pure technical efficiency, so that, Omani banks are operating with efficient level of outputs (optimal scale of efficiency). Regional developments are highlighted as one of the objectives within Omani 'Vision of 2020' (Tarawenh, 2006). That vision seeking diversification of Oman's economy aims for a greater role of private sector, particularly the banking sector. Overall, the rise in total factor productivity was essentially determined by technological change rather than technical efficiency which in line with hypothesis (1). This result implies that most banks tended to increase their spending on banking technology items such as ATMs, smart cards, internet banking, etc. to improve cost efficiency.

Table 5. Annual means of Malmquist Indices of banks in Oman

\begin{tabular}{|c|c|c|c|c|c|}
\hline Year & $\begin{array}{c}\text { Technical efficiency } \\
\text { change }\end{array}$ & $\begin{array}{l}\text { Technological } \\
\text { change }\end{array}$ & $\begin{array}{c}\text { Pure technical } \\
\text { efficiency change }\end{array}$ & $\begin{array}{c}\text { Scale efficiency } \\
\text { change }\end{array}$ & $\begin{array}{l}\text { Total factor } \\
\text { productivity* }\end{array}$ \\
\hline 2000 & 1.008 & 1.017 & 1.000 & 1.008 & 1.025 \\
\hline 2001 & 1.000 & 1.010 & 1.000 & 1.000 & 1.010 \\
\hline 2002 & 1.000 & 1.333 & 1.000 & 1.000 & 1.333 \\
\hline 2003 & 0.988 & 1.064 & 1.000 & 0.988 & 1.051 \\
\hline 2004 & 0.990 & 1.076 & 1.000 & 0.990 & 1.065 \\
\hline 2005 & 1.002 & 0.953 & 1.000 & 1.002 & 0.955 \\
\hline 2006 & 0.978 & 0.789 & 0.970 & 1.008 & 0.772 \\
\hline 2007 & 0.987 & 1.029 & 0.977 & 1.011 & 1.016 \\
\hline 2008 & 1.023 & 1.217 & 1.055 & 0.970 & 1.245 \\
\hline 2009 & 1.033 & 0.667 & 1.000 & 1.033 & 0.689 \\
\hline 2010 & 1.000 & 0.692 & 1.000 & 1.000 & 0.692 \\
\hline 2011 & 1.000 & 6.536 & 1.000 & 1.000 & 6.535 \\
\hline 2012 & 1.000 & 1.258 & 1.000 & 1.000 & 1.258 \\
\hline Mean & 1.001 & 1.142 & 1.000 & 1.001 & 1.143 \\
\hline
\end{tabular}




\subsection{Empirical results of Malmquist Index in Qatar}

In the State of Qatar, Table 6 presents MPI annual results for Qatari banks. Results indicate that banks in Qatar received on average total factor productivity of $7 \%$ increase for the study period. The overall improvement in productivity was associated with technological progress of $7 \%$ and a decline in technical efficiency of $1 \%$. As previously discussed, the efficiency can be decomposed into pure technical efficiency and scale efficiency. During the period of study, pure technical efficiency remained unchanged while the decrease in technical efficiency was merely the product of scale efficiency deterioration of $1 \%$, suggesting that commercial banks in Qatar have been operating at the operation optimal scale, but also that they have not been efficient in controlling their operating costs.
In more details, total factor productivity revealed a rise during years 2001, 2002, 2006, 2008 and 2011 as the most massive improvement was in 2011 of $88.1 \%$ as a result of increasing in technological change (technological progress) of $86 \%$ for the same year supporting the hypothesis (1). Paying attention to technological change, banks in Qatar exhibited progress in years 2001, 2002, 2006, 2008 and 2011. According to the Qatar Central Bank, a plausible reason for the increase in the technological change is associated with continuing investment in technological banking items. Overall, the empirical findings confirm that the total factor productivity growth, which originates solely from the technological change, is higher in a number of years and is attributed to the rapid adoption of new technology by Qatari banks.

Table 6. Annual means of Malmquist Indices of banks in Qatar

\begin{tabular}{|c|c|c|c|c|c|}
\hline Year & $\begin{array}{c}\text { Technical efficiency } \\
\text { change }\end{array}$ & $\begin{array}{c}\text { Technological } \\
\text { change }\end{array}$ & $\begin{array}{c}\text { Pure technical } \\
\text { efficiency change }\end{array}$ & $\begin{array}{c}\text { Scale efficiency } \\
\text { change }\end{array}$ & $\begin{array}{l}\text { Total factor } \\
\text { productivity* }\end{array}$ \\
\hline 2000 & 0.976 & 0.792 & 1.000 & 0.976 & 0.773 \\
\hline 2001 & 0.957 & 1.182 & 1.000 & 0.957 & 1.131 \\
\hline 2002 & 1.071 & 1.220 & 1.000 & 1.071 & 1.307 \\
\hline 2003 & 1.000 & 0.759 & 1.000 & 1.000 & 0.759 \\
\hline 2004 & 1.000 & 0.867 & 1.000 & 1.000 & 0.867 \\
\hline 2005 & 0.997 & 0.933 & 1.000 & 0.997 & 0.930 \\
\hline 2006 & 0.996 & 1.012 & 1.000 & 0.996 & 1.008 \\
\hline 2007 & 1.008 & 0.938 & 1.000 & 1.008 & 0.946 \\
\hline 2008 & 0.983 & 1.046 & 1.000 & 0.983 & 1.028 \\
\hline 2009 & 1.017 & 0.902 & 1.000 & 1.017 & 0.917 \\
\hline 2010 & 0.987 & 0.959 & 1.000 & 0.987 & 0.947 \\
\hline 2011 & 1.013 & 1.857 & 1.000 & 1.013 & 1.881 \\
\hline 2012 & 0.993 & 0.983 & 1.000 & 0.993 & 0.977 \\
\hline Mean & 0.999 & 1.007 & 1.000 & 0.999 & 1.007 \\
\hline
\end{tabular}

\subsection{Empirical results of Malmquist Index in Bahrain}

Table 7 revealed an annual increase of $10 \%$, the overall improvement in productivity for Bahraini banks over the study period was attributed to an average increase in technological change of $10 \%$ while efficiency (technical efficiency) remained unchanged. Findings in this table suggest that Bahraini banks recorded a rise in productivity during years 2000, 2002, 2003, 2006 and 2007, and decrease during 2001, 2004, 2005.
Regarding technical efficiency (efficiency), it can be noted that the annual mean of efficiency is unchanged but yearly it observed a decline during 2000, 2004, 2005 and showed an increase in 2001, 2006, and 2007. The decline in efficiency in some years is related mainly to a decrease in scale efficiency than to pure technical efficiency. The results suggest that Bahraini banks have been operating at optimal scale of operation.

Table 7. Annual means of Malmquist Indices of banks in Bahrain

\begin{tabular}{|c|c|c|c|c|c|}
\hline Year & $\begin{array}{c}\text { Technical efficiency } \\
\text { change }\end{array}$ & $\begin{array}{c}\text { Technological } \\
\text { change }\end{array}$ & $\begin{array}{c}\text { Pure technical } \\
\text { efficiency change }\end{array}$ & $\begin{array}{c}\text { Scale efficiency } \\
\text { change }\end{array}$ & $\begin{array}{c}\text { Total factor } \\
\text { productivity* }\end{array}$ \\
\hline 2000 & 0.999 & 1.056 & 1.000 & 0.999 & 1.055 \\
\hline 2001 & 1.001 & 0.940 & 1.000 & 1.001 & 0.941 \\
\hline 2002 & 1.000 & 1.110 & 1.000 & 1.000 & 1.110 \\
\hline 2003 & 1.000 & 1.243 & 1.000 & 1.000 & 1.243 \\
\hline 2004 & 0.980 & 0.957 & 1.000 & 0.980 & 0.938 \\
\hline 2005 & 0.965 & 0.539 & 1.000 & 0.965 & 0.520 \\
\hline 2006 & 1.050 & 1.401 & 1.000 & 1.050 & 1.471 \\
\hline 2007 & 1.006 & 0.893 & 1.000 & 1.006 & 0.899 \\
\hline 2008 & 1.000 & 1.078 & 1.000 & 1.000 & 1.078 \\
\hline 2009 & 1.000 & 0.971 & 1.000 & 1.000 & 0.971 \\
\hline 2010 & 1.000 & 0.927 & 1.000 & 1.000 & 0.927 \\
\hline 2011 & 1.000 & 1.200 & 1.000 & 1.000 & 1.200 \\
\hline 2012 & 1.000 & 1.109 & 1.000 & 1.000 & 1.109 \\
\hline Mean & 1.000 & 1.010 & 1.000 & 1.000 & 1.010 \\
\hline
\end{tabular}


The overall increase in total factor productivity was attributed solely to technological progress and hypothesis 1 is supported. A possible reason for the increase in technological change may be related to investment decisions in sophisticated systems and equipment as well as banking financial liberalisation which have been taking place for that period. Bahraini banking has witnessed a presence of foreign banks as those banks have a crucial effect on domestic banks to move further in investing in technological innovations.

The Bahraini banking sector has also shown a reaction to the changes in the global nature of business which leads banks in Bahrain to pursue technological progress and invest more in retail banking technologies such as internet banking (E-Banking), ATMs and wireless banking. Therefore, in order to maintain market share in the market, commercial banks should invest more in new technology to avoid losing customers because of some factors attributed to easy access and competitive prices.

\subsection{Empirical results of Malmquist Index in Kuwait}

Table 8 presents the annual means of MPI results for banks operating in the State of Kuwait. Findings tell that over the study period, there was a mean annual growth in total factor productivity for Kuwaiti banks of $50 \%$. Such improvement in productivity during that period was attributed solely to an increase in technological change (progress) of 50\%. The overall increase in factor productivity is driven by technological progress only, according to results year by year; it seems to indicate that Kuwaiti banks experienced a growth in productivity during years 2000, 2001, 2002, 2003, 2007, 2010, 2011 and 2012. The highest improvement in productivity was in 2011 of $40 \%$, due to the highest technological change of $44 \%$. A probable reason for the progress in technology during those years could be associated with financial reforms and deregulation that have occurred in the last two decades which led to growth of assets of commercial banks with more expertise to invest in sophisticated system and equipment. Such a growth continued rapidly as a result of adoption of new information technology by Kuwaiti banking sector, and hence they moved faster for technological innovation. Such findings are in line with hypothesis (1).

\subsection{Empirical results of Malmquist Index in Egypt}

As depicted in Table 9, the MPI findings show that Egyptian banks have observed a decrease in total factor productivity by $7.8 \%$. The results seem to suggest that Egyptian commercial revealed a total factor productivity decline during the years 2000, 2001, 2002, 2004, 2006, 2007, 2008, 2009, 2011 and 2012 which in turns does not support the hypothesis (1), whereas, total productivity was recorded to increase during the years 2003, 2005 and 2010. Over the examined period, technical efficiency and technological change exposed an annual mean decline of $1.4 \%$ and $6.6 \%$ respectively. On the other hand, it can be seen that technical efficiency (efficiency) of banks in Egypt were observed to have a decrease by $1.4 \%$.

Table 8. Annual means of Malmquist Indices of banks in Kuwait

\begin{tabular}{|c|c|c|c|c|c|}
\hline Year & $\begin{array}{c}\text { Technical efficiency } \\
\text { change }^{* * *}\end{array}$ & $\begin{array}{l}\text { Technological } \\
\text { change }\end{array}$ & $\begin{array}{c}\text { Pure technical } \\
\text { efficiency change }\end{array}$ & $\begin{array}{c}\text { Scale efficiency } \\
\text { change }\end{array}$ & $\begin{array}{l}\text { Total factor } \\
\text { productivity }\end{array}$ \\
\hline 2000 & 0.989 & 1.108 & 1.000 & 0.989 & 1.095 \\
\hline 2001 & 0.983 & 1.093 & 1.000 & 0.983 & 1.074 \\
\hline 2002 & 1.020 & 1.109 & 1.000 & 1.020 & 1.132 \\
\hline 2003 & 0.991 & 1.328 & 1.000 & 0.991 & 1.316 \\
\hline 2004 & 1.018 & 0.966 & 1.000 & 1.018 & 0.983 \\
\hline 2005 & 1.000 & 0.932 & 1.000 & 1.000 & 0.932 \\
\hline 2006 & 1.000 & 0.664 & 1.000 & 1.000 & 0.664 \\
\hline 2007 & 1.000 & 1.118 & 1.000 & 1.000 & 1.118 \\
\hline 2008 & 1.000 & 0.825 & 1.000 & 1.000 & 0.825 \\
\hline 2009 & 1.000 & 0.992 & 1.000 & 1.000 & 0.992 \\
\hline 2010 & 1.000 & 1.310 & 1.000 & 1.000 & 1.310 \\
\hline 2011 & 0.973 & 1.438 & 1.000 & 0.973 & 1.399 \\
\hline 2012 & 1.028 & 1.020 & 1.000 & 1.028 & 1.049 \\
\hline Mean & 1.000 & 1.050 & 1.000 & 1.000 & 1.050 \\
\hline
\end{tabular}

Table 9. Annual means of Malmquist Indices of banks in Egypt

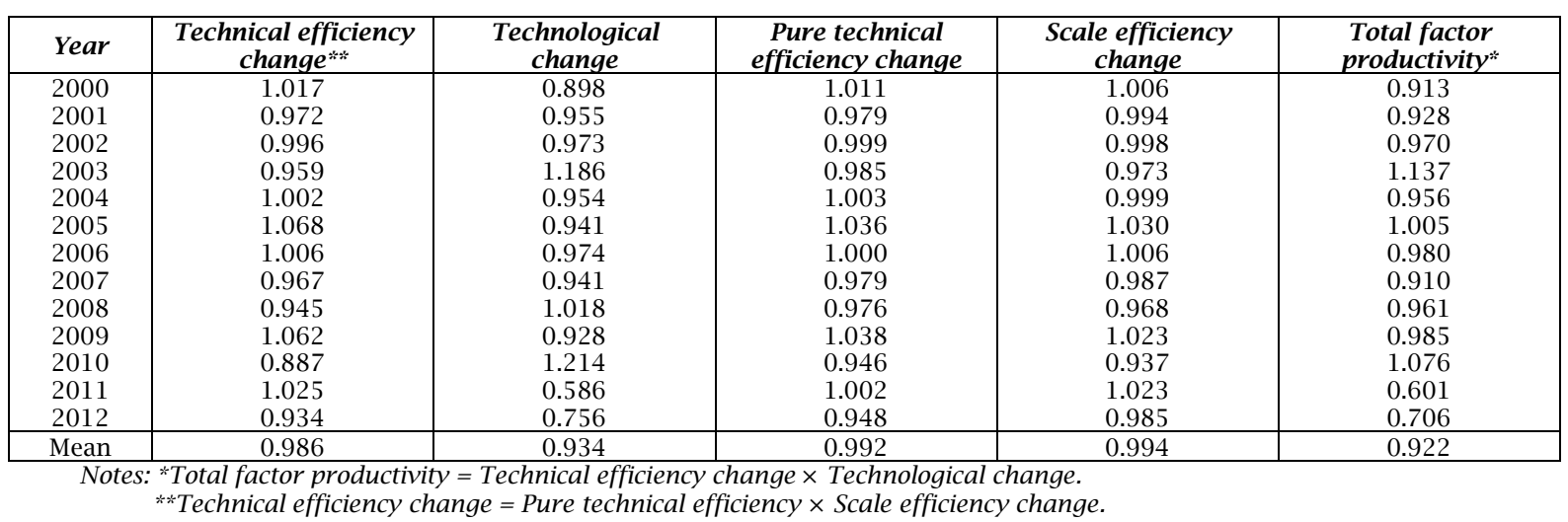


According to the results, this decline was attributed to regress in pure technical efficiency and scale efficiency as there is no significant difference between both of them (pure technical efficiency and scale efficiency). The results suggest that banks in Egypt have been managerially inefficient in managing their operating expenditures.

Although the financial services and banking reforms have a critical element of economic reform presented in 1990s in Egypt, results for this case implies that regulators, the central bank, and bank managers in Egypt should pay more attention to technical efficiency of banks as results confirm that banks have not been operating with efficient level of operation and inefficient in controlling their operating costs. Furthermore, regulators should go further to encourage banks investing in technology such as ATMs, interment banking and wireless in order to reach cost efficiency and to avoid losing customers.

\subsection{Empirical results of Malmquist Index in Jordan}

Estimation of annual mean of MPI results for Jordanian banks are presented in Table 10. Results for the study period imply that commercial banks in Jordan have revealed an average increase of total factor productivity of $5.6 \%$ and hence supporting hypothesis (1). Findings seem to suggest that the overall improvement in total factor productivity was attributed to a technological change of $5.1 \%$ rather than technical efficiency of $0.5 \%$, which reflects that the increased in technological change and its positive effects on productivity are due to deregulation and the liberalisation of the banking system and the General Agreement on Trade in Services (GATS) signed by the Jordon government in 2001. According to the literature (Al-Fayoumi, 2009) highlighted that the banking sector in Jordan is introducing new banking products and investing more in technological banking items and human resources. Additionally, foreign banks that operate in Jordan have has put a pressure on domestic banks to move much faster in investing in technological innovation to achieve the cost efficiency and gaining a competitive edge.

It can be noted from the table that the technical efficiency of banks in Jordan has increased by $0.5 \%$, but this is attributed mainly to scale efficiency rather than pure technical efficiency. The results of this case indicate that banks in Jordan have been operating at optimal scale or with efficient level of outputs, but that they did not do so efficiently by managing their operating costs. Generally, due to the (GATS), it is imperative for Jordanian banks to pursue technological progress as more domestic banks offer the products introduced by foreign investors. Results also suggest that commercial banks have been moving toward investing in retail banking technologies such as ATMs, software, internet banking.

Table 10. Annual means of Malmquist Indices of banks in Jordan

\begin{tabular}{|c|c|c|c|c|c|}
\hline Year & $\begin{array}{c}\text { Technical efficiency } \\
\text { change }\end{array}$ & $\begin{array}{c}\text { Technological } \\
\text { change }\end{array}$ & $\begin{array}{c}\text { Pure technical } \\
\text { efficiency change }\end{array}$ & $\begin{array}{c}\text { Scale efficiency } \\
\text { change }\end{array}$ & $\begin{array}{l}\text { Total factor } \\
\text { productivity }\end{array}$ \\
\hline 2000 & 1.010 & 0.978 & 1.004 & 1.006 & 0.988 \\
\hline 2001 & 1.010 & 1.051 & 1.003 & 1.007 & 1.062 \\
\hline 2002 & 1.016 & 1.053 & 0.998 & 1.018 & 1.070 \\
\hline 2003 & 0.960 & 1.299 & 1.002 & 0.958 & 1.247 \\
\hline 2004 & 0.962 & 1.140 & 0.988 & 0.973 & 1.097 \\
\hline 2005 & 1.071 & 0.972 & 1.012 & 1.059 & 1.041 \\
\hline 2006 & 1.010 & 1.003 & 1.000 & 1.010 & 1.014 \\
\hline 2007 & 1.034 & 1.129 & 1.000 & 1.034 & 1.167 \\
\hline 2008 & 0.969 & 1.095 & 0.973 & 0.996 & 1.060 \\
\hline 2009 & 1.030 & 0.609 & 1.028 & 1.002 & 0.627 \\
\hline 2010 & 0.974 & 1.597 & 0.974 & 1.000 & 1.556 \\
\hline 2011 & 1.014 & 1.305 & 1.021 & 0.994 & 1.323 \\
\hline 2012 & 1.007 & 0.776 & 1.006 & 1.002 & 0.781 \\
\hline Mean & 1.005 & 1.051 & 1.001 & 1.004 & 1.056 \\
\hline
\end{tabular}

\subsection{Empirical results of Malmquist Index in Lebanon}

The annual means of MPI of Lebanese banks are presented in Table 11 . It shows that over the study period, the annual mean of total factor productivity for commercial banks operating in Lebanon have experienced regressed by $2 \%$ and therefore hypothesis (1) is not supported. These findings suggest that commercial banks in Lebanon regressed in total productivity during the years 2000, 2001, 2002, 2003, 2004, 2008 and 2011 while total productivity increased during the years 2005, 2006 , 2007, 2009, 2010, 2012. According to the table, the growth in productivity can be attributed to technological change rather than technical efficiency (efficiency). These results are in line with Turk-Ariss (2008) as he highlighted that the government of Lebanon plans to join the World Trade Organisation
(WTO) which justifies the need for an efficient and more competitive banking sector. As a result of such matter, Lebanon has made a heavy investment in information technology and technological innovations.

However, the efficiency of commercial banks in Lebanon has decreased for annual mean of banks by $7 \%$, which can be attributed to a decrease in the annual mean of pure technical efficiency of $3 \%$ and scale efficiency of $5 \%$. Results suggest that commercial banks operating in Lebanon have not been working at the optimal scale of operation and controlling their operating expenses. Overall, the previous results show that the monetary authority, regulators and bank managers should reconsider their policies to improve the efficiency of banks in terms of operating at optimal outputs and controlling their operating expenses efficiently. 
Table 11. Annual means of Malmquist Indices of banks in Lebanon

\begin{tabular}{|c|c|c|c|c|c|}
\hline Year & $\begin{array}{c}\text { Technical efficiency } \\
\text { change }\end{array}$ & $\begin{array}{l}\text { Technological } \\
\text { change }\end{array}$ & $\begin{array}{c}\text { Pure technical } \\
\text { efficiency change }\end{array}$ & $\begin{array}{c}\text { Scale efficiency } \\
\text { change }\end{array}$ & $\begin{array}{c}\text { Total factor } \\
\text { productivity* }\end{array}$ \\
\hline 2000 & 0.992 & 0.965 & 1.007 & 0.985 & 0.957 \\
\hline 2001 & 1.007 & 0.918 & 1.000 & 1.007 & 0.924 \\
\hline 2002 & 1.021 & 0.920 & 1.003 & 1.018 & 0.939 \\
\hline 2003 & 0.989 & 0.976 & 1.000 & 0.989 & 0.965 \\
\hline 2004 & 1.006 & 0.910 & 0.998 & 1.008 & 0.916 \\
\hline 2005 & 1.011 & 1.013 & 1.001 & 1.010 & 1.024 \\
\hline 2006 & 1.000 & 1.044 & 1.001 & 0.999 & 1.044 \\
\hline 2007 & 0.980 & 1.054 & 0.979 & 1.000 & 1.032 \\
\hline 2008 & 0.975 & 1.014 & 0.994 & 0.981 & 0.989 \\
\hline 2009 & 0.976 & 1.063 & 1.027 & 0.950 & 1.037 \\
\hline 2010 & 0.949 & 1.137 & 0.998 & 0.951 & 1.078 \\
\hline 2011 & 0.997 & 0.865 & 0.930 & 1.072 & 0.862 \\
\hline 2012 & 1.005 & 1.003 & 1.031 & 0.975 & 1.008 \\
\hline Mean & 0.993 & 0.988 & 0.997 & 0.995 & 0.981 \\
\hline
\end{tabular}

\subsection{Empirical results of Malmquist Index in Morocco}

As introduced in Table 12, the MPI results show that commercial banks operating in Morocco have, on average, revealed a growth in total factor productivity of $4 \%$ to confirm hypothesis (1). Such growth resulted from the increase in technological change of $4 \%$ and annual technical efficiency remained unchanged. This result suggests that Moroccan banks have not operated at constant return to scale and they have not efficiently selected their inputs combinations.
However, technological change which is the main source of productivity growth of $4 \%$ improved during the years 2001, 2002, 2004, 2006, 2007, 2008, 2009 and 2011. The plausible reason for the increase in technological change could be related to a mega-merger programme which has led to large banks with good abilities to improve their productivity through capital investment in information technology. Furthermore, Morocco witnessed a comprehensive financial reform, particularly in the banking industry before 1990s, as the state owns merely 29\% of banking assets (Ben Naceur, 2011).

Table 12. Annual means of Malmquist Indices of banks in Morocco

\begin{tabular}{|c|c|c|c|c|c|}
\hline Year & $\begin{array}{c}\text { Technical efficiency } \\
\text { change }\end{array}$ & $\begin{array}{l}\text { Technological } \\
\text { change }\end{array}$ & $\begin{array}{c}\text { Pure technical } \\
\text { efficiency change }\end{array}$ & $\begin{array}{c}\text { Scale efficiency } \\
\text { change }\end{array}$ & $\begin{array}{l}\text { Total factor } \\
\text { productivity }\end{array}$ \\
\hline 2000 & 0.820 & 0.814 & 1.000 & 0.820 & 0.668 \\
\hline 2001 & 1.165 & 1.019 & 1.000 & 1.165 & 1.187 \\
\hline 2002 & 0.920 & 1.088 & 1.000 & 0.920 & 1.001 \\
\hline 2003 & 1.002 & 0.995 & 1.000 & 1.002 & 0.997 \\
\hline 2004 & 1.135 & 1.099 & 1.000 & 1.135 & 1.247 \\
\hline 2005 & 0.961 & 0.913 & 1.000 & 0.961 & 0.878 \\
\hline 2006 & 1.007 & 1.094 & 1.000 & 1.007 & 1.102 \\
\hline 2007 & 1.033 & 1.299 & 1.000 & 1.033 & 1.341 \\
\hline 2008 & 0.993 & 1.125 & 1.000 & 0.993 & 1.117 \\
\hline 2009 & 1.007 & 1.018 & 1.000 & 1.007 & 1.025 \\
\hline 2010 & 0.998 & 1.000 & 1.000 & 0.998 & 0.999 \\
\hline 2011 & 1.002 & 1.198 & 1.000 & 1.002 & 1.200 \\
\hline 2012 & 1.000 & 0.953 & 1.000 & 1.000 & 0.953 \\
\hline Mean & 1.000 & 1.040 & 1.000 & 1.000 & 1.040 \\
\hline
\end{tabular}

\subsection{Empirical results of Malmquist Index in Tunisia}

The results of the annual means of MPI for commercial banks operating in Tunisia are reported in Table 13. According to the results, Tunisian banks have average record growth in total factor productivity of $1.4 \%$ and this result supports the hypothesis (1). The overall improvement for the whole period was attributed to a rise in technological change of $0.8 \%$ and technical efficiency increase of $0.6 \%$.
Findings suggest that commercial banks in Tunisia observed total productivity growth over the years 2004, 2005, 2006, 2008, 2010 and 2011, whereas productivity is shown to have decreased during the years 2007, 2009 and 2012. It can be noted from the table that efficiency of banks has obtained an annual mean growth of $0.6 \%$, mostly related to scale efficiency rather than to pure technical efficiency, indicating that commercial banks operating in Tunisia have been operating at optimal level of outputs but have not been efficient in managing their operating expenses. 
Table 13. Annual means of Malmquist Indices of banks in Tunisia

\begin{tabular}{|c|c|c|c|c|c|}
\hline Year & $\begin{array}{c}\text { Technical efficiency } \\
\text { change }\end{array}$ & $\begin{array}{l}\text { Technological } \\
\text { change }\end{array}$ & $\begin{array}{c}\text { Pure technical } \\
\text { efficiency change }\end{array}$ & $\begin{array}{c}\text { Scale efficiency } \\
\text { change }\end{array}$ & $\begin{array}{c}\text { Total factor } \\
\text { productivity* }\end{array}$ \\
\hline 2000 & 0.980 & 1.045 & 1.002 & 0.978 & 1.024 \\
\hline 2001 & 1.027 & 0.797 & 1.003 & 1.024 & 0.819 \\
\hline 2002 & 1.032 & 1.037 & 1.002 & 1.030 & 1.070 \\
\hline 2003 & 1.000 & 1.024 & 0.983 & 1.017 & 1.023 \\
\hline 2004 & 1.000 & 1.024 & 0.983 & 1.017 & 1.023 \\
\hline 2005 & 1.032 & 1.037 & 1.002 & 1.030 & 1.070 \\
\hline 2006 & 0.945 & 1.213 & 0.973 & 0.971 & 1.146 \\
\hline 2007 & 1.027 & 0.797 & 1.003 & 1.024 & 0.819 \\
\hline 2008 & 0.980 & 1.045 & 1.002 & 0.978 & 1.024 \\
\hline 2009 & 1.036 & 0.925 & 1.039 & 0.997 & 0.958 \\
\hline 2010 & 1.013 & 1.130 & 0.992 & 1.020 & 1.144 \\
\hline 2011 & 1.007 & 1.042 & 0.995 & 1.013 & 1.050 \\
\hline 2012 & 1.017 & 0.921 & 1.010 & 1.006 & 0.937 \\
\hline Mean & 1.006 & 1.008 & 1.000 & 1.006 & 1.014 \\
\hline
\end{tabular}

\section{TOTAL FACTOR PRODUCTIVITY TOBIT REGRESSION FINDINGS}

In this stage, this paper uses the Tobit regression model to obtain the impacts of bank-specific, macroeconomic variables and year and countries effects on the total factor productivity of MENA banks. Since total factor productivity results obtained from the DEA, in this case, they are truncated data for which ordinary least squares (OLS) is not appropriate for such purpose.

Starting by the variable measuring bank risk (LOANAST) net loans to total assets, it exhibits a negative relationship and statistically significant at $10 \%$ level in tables 14 and 15 . Also recorded negative and significantly relationship at 5\% level in Table 14
Such a result is in line with Sufian and Habibullah (2013) who indicates a positive relationship between the productivity of banks and the level of liquidity held by banks. The ratio is considered high if banks are less liquid (lending more), so that results emphasise the more productive banks are the more likely they are to be more liquid. One reason which could explain why banks with less liquidity are less productive is related to monitoring cost increases for higher amounts of loans in terms of originated, serviced and monitored as suggested by Ben Naceur (2011). The negative impact of liquidity risk on bank productivity is explained by the fact that less liquid banks are more involved in financing risky loans which in turns lead to have nonperforming loans.

Table 14. Tobit regression analysis to investigate determinants of banking productivity (TFPCH)

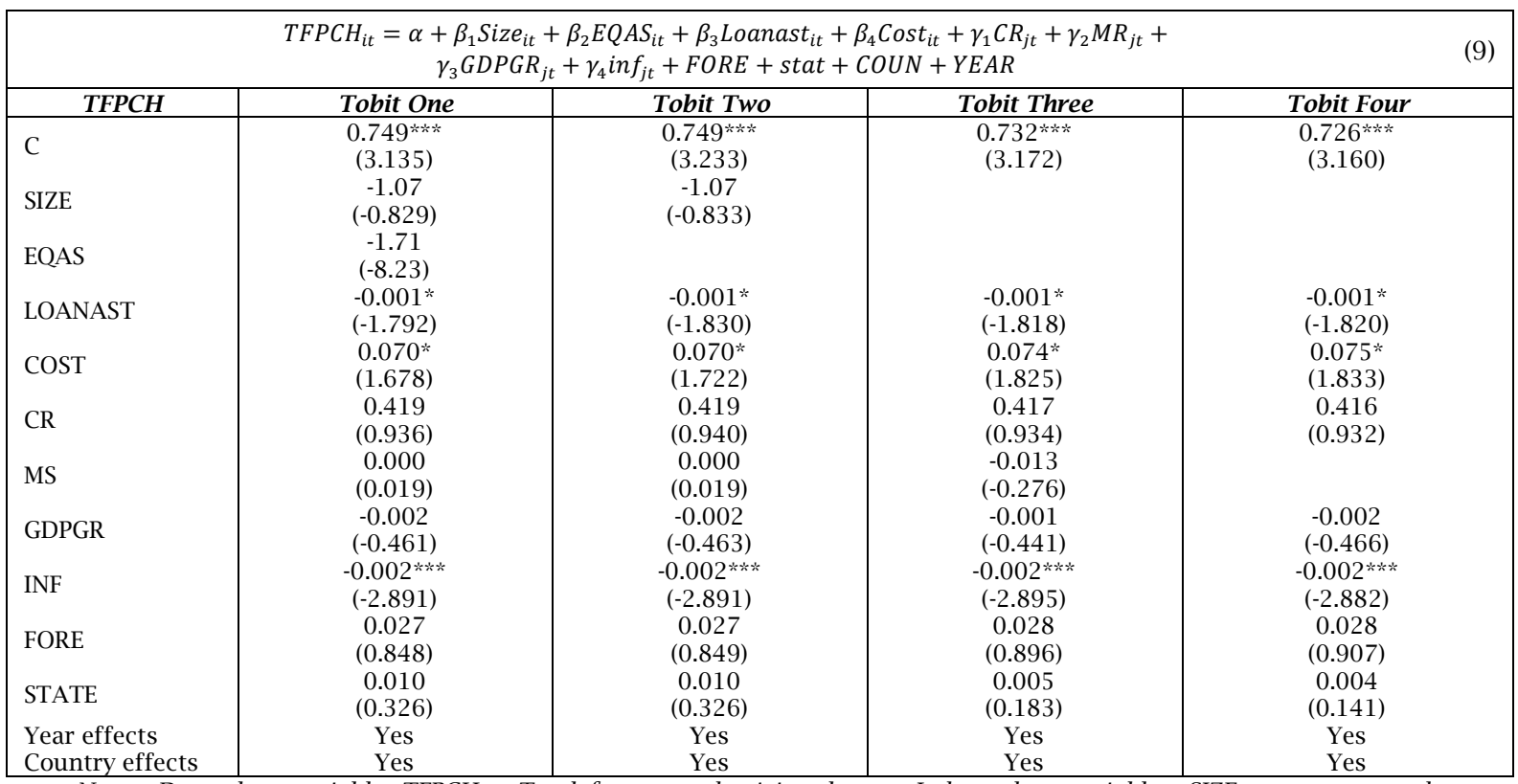

Notes: Dependent variable: TFPCH $=$ Total factor productivity change. Independent variables: SIZE = average total assets, $E Q A S=$ equity to average total assets, LOANAST = net loans to average total assets, CR = the Herfindahl- Hirschman Index (HHI), MS = market share, GDPGR = real gross domestic growth, INF = real inflation rate, FORE = dummy for foreign ownership, STATE = dummy for state ownership.

* Significant at the 10\% level. ** Significant at the 5\% level. *** Significant at 1\% level.

Regarding the effect of banks size (SIZE) measured by total assets, the empirical results show a negative coefficient of the size variable but insignificant. Such a finding is supported by
Kosmidou (2008) and Sufian and Habibullah (2013) as they pointed out that growing in size could have a negative impact on the performance of a bank, as a result of more bureaucratic procedures. Concerning 
the level of capital adequacy (EQAS), results are mixed as some regressions exhibited a negative relationship and were statistically insignificant with total factor productivity of banks. Based on these results there is no evidence for the relationship between productivity of MENA banks and their capital adequate.

In respect to the impact of market concentration and market share on banking productivity, results show a positive but insignificant sign: the empirical findings of this variable do not support the structure-conductperformance (SCP) hypothesis. On the other hand, using market share as the market power indicator exhibited a negative value but also insignificant, so that the results do not provide strong evidence that banks with higher market share or more productive. Turning to the effect of a bank's cost management on its productivity; it is interesting to observe that the coefficients of COST revealed a positive and significant impact on banks' total productivity at the $5 \%$ and $10 \%$ level in all regressions. Findings indicate that an increase (decrease) in costs improves (reduce) productivity of banks operating in MENA economies. It seems to suggest that expenses preference behaviour, in this case, leads banks to increase their productivity. A reasonable justification for this result is that higher remunerations package would be required by highly qualified and professional management as well as employee's incentives programmes which can encourage or promote a bank's employees to work efficiently and produce quantifiable products and services, and therefore a positive relationship with productivity of banks in line with (Sathye, 2003).

Table 15. Tobit regression analysis to investigate determinants of banking productivity (TFPCH)

\begin{tabular}{|c|c|c|c|c|}
\hline \multicolumn{5}{|c|}{$\begin{array}{c}\text { TFPCH }_{i t}=\alpha+\beta_{1} \text { Size }_{i t}+\beta_{2} E_{Q A S_{i t}}+\beta_{3} \text { Loanast }_{i t}+\beta_{4} \text { Cost }_{i t}+\gamma_{1} C R_{j t}+\gamma_{2} M R_{j t}+ \\
\gamma_{3} \text { GDPGR }_{j t}+\gamma_{4} \text { inf }_{j t}+\text { FORE }+ \text { stat }+ \text { COUN }+Y E A R\end{array}$} \\
\hline TFPCH & Tobit One & Tobit Two & Tobit Three & Tobit Four \\
\hline C & $\begin{array}{c}0.963^{*} \text { *** } \\
(5.444)\end{array}$ & 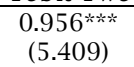 & $\begin{array}{c}0.950 * * * * \\
(5.414)\end{array}$ & $\begin{array}{c}0.944 \text { * } \\
(5.422)\end{array}$ \\
\hline SIZE & $\begin{array}{c}-1.11 \\
(-0.867)\end{array}$ & & & \\
\hline EQAS & $\begin{array}{l}-0.000 \\
(-0.375)\end{array}$ & $\begin{array}{c}-0.000 \\
(-0.305)\end{array}$ & & \\
\hline LOANAST & $-0.001 *$ & $-0.001^{*}$ & $-0.001^{*}$ & $-0.001 *$ \\
\hline & $0.001 * *$ & $0.001^{* * *}$ & $0.001 * *$ & $\begin{array}{l}(-1.707) \\
0.001 * *\end{array}$ \\
\hline COST & $(1.920)$ & $(2.016)$ & $(2.028)$ & $(2.039)$ \\
\hline $\mathrm{CR}$ & 0.444 & 0.439 & 0.426 & 0.425 \\
\hline & $(0.992)$ & $(0.980)$ & $(0.956)$ & $(0.954)$ \\
\hline MS & $\begin{array}{c}0.001 \\
(0.032)\end{array}$ & $\begin{array}{c}-0.012 \\
(-0.269)\end{array}$ & $\begin{array}{c}-0.011 \\
(-0250)\end{array}$ & \\
\hline$C D P P$ & -0.002 & -0.002 & -0.002 & -0.002 \\
\hline GDPGR & $(-0.526)$ & $(-0.513)$ & $(-0.533)$ & $(-0.556)$ \\
\hline JNF & $-0.002^{* * * *}$ & $-0.002^{* * * *}$ & $-0.002 * * *$ & $-0.002^{* * * *}$ \\
\hline INF & $(-2.939)$ & $(-2.945)$ & $(-2.942)$ & $(-2.931)$ \\
\hline FORE & 0.027 & 0.029 & 0.029 & 0.029 \\
\hline FURE & $(0.854)$ & $(0.909)$ & $(0.927)$ & $(0.937)$ \\
\hline STATE & 0.009 & 0.004 & 0.004 & 0.003 \\
\hline SIAIE & $(0.298)$ & $(0.149)$ & $(0.161)$ & $(0.124)$ \\
\hline Year effects & Yes & Yes & Yes & Yes \\
\hline Country effects & Yes & Yes & Yes & Yes \\
\hline
\end{tabular}

Notes: Dependent variable: TFPCH $=$ Total factor productivity change. Independent variables: SIZE = average total assets, EQAS = equity to average total assets, LOANAST = net loans to average total assets, CR = the Herfindahl- Hirschman Index (HHI), MS = market share, GDPGR = real gross domestic growth, INF = real inflation rate, FORE = dummy for foreign ownership, STATE = dummy for state ownership.

* Significant at the 10\% level. ** Significant at the 5\% level. *** Significant at 1\% level.

Referring to the impact of macroeconomic indicators on the productivity of banks, results of (GDPGR) growth in gross domestic product are not consistent with the theory that banks tend to be more productive in a growing economy, since all results in all regressions are negative and insignificant as well. In respect to inflation (INF), results show that the inflation variable has a negative and significant relationship with the productivity of commercial banks. It could be explained that banks during the study period, have not anticipated a level of inflation which allowed them to adjust interests rates and consequently improve productivity. Also, during times of growth, banks are more encouraged to provide loans which in turns require additional costs to monitor and screen. Therefore higher proportions of loans are observed the highest operational costs. Finally, to account market changes, financial reforms and technological changes on productivity of MENA banks, year and country effects have been introduced in the models for this study. All years in all regressions are compared to the basic year 1999, and all countries are compared to Bahrain. The general findings from the table below indicate that total factor productivity of commercial banks are mostly higher than those of the basic year implying that productivity has improved during the examined period of this study. These improvements could be linked to the fact that banking sector in the MENA countries has witnessed major financial reforms programmes during this period which led MENA banks to be engaged in allocating more capital investments in technology including ATMs, internet banking services, and increasing the availability of debit and credit cards. 
Table 16. Tobit regression analysis to investigate determinants of banking productivity (TFPCH)

\begin{tabular}{|c|c|c|c|c|}
\hline \multicolumn{5}{|c|}{$\begin{array}{c}\text { TFPCH }_{i t}=\alpha+\beta_{1} \text { Size }_{i t}+\beta_{2} E_{\text {EAS }}+\beta_{3} \text { Loanast }_{i t}+\beta_{4} \text { Cost }_{i t}+\gamma_{1} \text { CR }_{j t}+\gamma_{2} M R_{j t}+ \\
\gamma_{3} \text { GDPGR }_{j t}+\gamma_{4} \text { inf }_{j t}+\text { FORE }+ \text { stat }+ \text { COUN }+ \text { YEAR }\end{array}$} \\
\hline TFPCH & Tobit One & Tobit Two & Tobit Three & Tobit Four \\
\hline 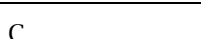 & $0.965^{* * * *}$ & 1.018 & 0.796 *** & $0.862 * * *$ \\
\hline & $(5.453)$ & $(6.037)$ & $(9.111)$ & $(11.20)$ \\
\hline SIZE & -1.11 & 2.65 & -3.85 & 9.15 \\
\hline JILL & $(-0.865)$ & $(0.206)$ & -0.336150 & $(0.818)$ \\
\hline EOAS & -0.00 & 0.000 & $0.003^{*}$ & 0.002 \\
\hline EQAS & $(-0.068)$ & $(0.082)$ & (1.795) & $(1.468)$ \\
\hline IOANAST & $-0.001 *$ & -0.001 & $0.001 \% *$ & $0.001^{* * *}$ \\
\hline LUANASI & $(-1.736)$ & $(-1.295)$ & $(2.468)$ & $(2.324)$ \\
\hline & $0.001^{*}$ & 0.000 & 0.000 & 0.000 \\
\hline $\cos 1$ & $(1.822)$ & (1.503) & $(1.008)$ & $(1.200)$ \\
\hline $\mathrm{CR}$ & 0.432 & -0.096 & $0.490 * * *$ & $0.367^{* * *}$ \\
\hline CR & $(0.966)$ & $(-0.227)$ & $(3.182)$ & $(2.404)$ \\
\hline & 0.002 & -0.024 & -0.012 & -0.053 \\
\hline MS & $(0.042)$ & $(-0.490)$ & $(-0.245)$ & $(-1.058)$ \\
\hline GDPGR & -0.002 & -0.000 & -0.004 & -0.003 \\
\hline GDPGK & $(-0.494)$ & $(-0.121)$ & $(-1.015)$ & $(-0.851)$ \\
\hline & $-0.002 * * *$ & 0.000 & $-0.000 * * *$ & -0.000 \\
\hline INF & $(-2.924)$ & $(0.545)$ & $(-2.277)$ & $(-0.486)$ \\
\hline FORE & 0.028 & 0.033 & 0.009 & 0.015 \\
\hline & $(0.885)$ & (1.014) & $(0.309)$ & $(0.501)$ \\
\hline & 0.009 & 0.003 & -0.010 & -0.007 \\
\hline SIAIE & $(0.312)$ & $(0.105)$ & $(-0.331)$ & $(-0.243)$ \\
\hline Year effects & Yes & Yes & Yes & Yes \\
\hline Country effects & Yes & Yes & Yes & Yes \\
\hline
\end{tabular}

\section{CONCLUSION}

This paper provides empirical evidence on the drivers of total factor productivity in MENA banking economies and how it is influenced by bank-specific variables, market structure and macroeconomic variables. Firstly, I employed the non-parametric frontier DEA using MPI to estimate the total factor productivity for commercial banks operating in eleven MENA countries over the period 1999-2012. Using the MPI allows the determination not only the total factor productivity of banks, but also the frontier growth (technological change) and the optimal resource utilisation (technical efficiency change). The obtained MPI results suggest that banks in the Gulf countries have exhibited productivity progress mainly due to the technological progress rather than efficiency change. Such findings imply that banks in these countries are moving toward spending huge investments on retail banking technologies such as ATMs, internet banking, wireless banking and smart cards to achieve cost efficiency. However, other MENA countries have also experienced productivity progress, due to technological changes and technical efficiency for Jordanian banks and from technological changes alone for Moroccan commercial banks. On the other hand, banks in Egypt and Lebanon have recorded decline in their productivity as a result of regress in technological changes and efficiency. This might highlighted the relative ineffectiveness of social and economic policies, and thus appropriate actions would be necessary to reverse such a trend.
Secondly, the Tobit model is employed to investigate whether the financial liberalisation which has taken place in that period and other variables such as size of banks, risk, market structure and macroeconomic variables have had an effect on the productivity of MENA banks. The results of Tobit model suggest that the financial liberalisation would enable MENA banks to be more productive for the period 1999-2012 because of sound management practices, more investment in technology and positive impact of mergers and acquisitions.

In respect to bank-specific factors, size of banks and their liquidity measures seem to exert a regressive impact on total factor productivity, meaning growing in size could create a negative impact on the performance of a bank. Regarding the bank risk variable (LOANAST) also has a negative association with total factor productivity of MENA banks and a plausible reason for such a matter can be found in the increased costs of monitoring required by a higher proportion of loans. However, the impact of a bank's cost suggests that expenses behaviour leads banks to be more productive confirming that highly qualified and professional managers may require a higher which can encourage bank's staff to produce good quality of banking services.

Despite improvements in productivity in banks operating in Gulf countries, Morocco, Jordan and Tunisia, I suggest that further reforms may be desired in order to obtain the optimal utilisation of capacities as well as making the greatest use of resources. Overall, different mix of policies should be adopted depending on the characteristics of the banking system on the examined countries. 


\section{REFERENCES}

1. Abiad, A., \& Mody, A. (2003). Financial reform: What shakes it? What shapes it? (IMF Working Paper No. 03/70, Washington: International Monetary Fund ).

2. Abuzayed, B., Al-Fayoumi, N., \& Gharaibeh, H. (2012). Competition in MENA countries banking markets. International Journal of Financial Services Management (IJFSM), 5(3), 272-300. https://doi.org/10.1504/ IJFSM.2012.046951

3. Al Hammadi, K. F., (2013). A comparative study of technical efficiency in GCC Islamic financial institutions during the global financial crisis using Malmquist-type data envelopment analysis (Master dissertation in Finance and Banking, the British University in Dubai).

4. Al Shamsi, F. S., Aly, H. Y., \& El-Bassiouni, M. Y. (2009). Measuring and explaining the efficiencies of the United Arab Emirates banking system. Applied Economics, 41(27), 3305-3519. https://doi.org/10.1080/ 00036840801964773

5. Al-Muharrami, S., \& Matthews, K. (2009). Market power versus efficient-structure in Arab GCC banking. Applied Financial Economics, 19(18), 1487-1496. https://doi.org/10.1080/09603100902845478

6. Ben Abdelkader, I., \& Mansouri, F. (2013). Competitive conditions of the Tunisian banking industry: An application of the Panzar-Rosse model. African Development Review, 25(4), 526-536. https://doi.org/10.1111/ 1467-8268.12047

7. Ben Naceur, S., Ben-Khedhiri, H., \& Casu, B. (2011). What drives the performance of selected MENA bank? A metafrontier analysis (IMF Working Paper No. 11/34). Retrieved from the International Monetary Fund website: https://www.imf.org/external/pubs/ft/wp/2011/wp1134.pdf

8. Ben Naceur, S., Ben-Khedhiri, H., \& Casu, B. (2009). What drives the efficiency of selected MENA banks? A metafrontier analysis (Economic Research Forum, Working Paper Series No. 499).

9. Berger, A. N., \& Humphrey, D. B. (1997). Efficiency of financial institutions: International survey and direction for future research. European Journal of Operational Research, 98(2), 175-212. https://doi.org/10.1016/S03772217(96)00342-6

10. Boudriga, A., Taktak, N. B., \& Jellouli, S. (2009). Bank specific, business and institutional environment determinants of nonperforming loans: Evidence from MENA countries. Paper presented at the 16th Annual Conference, November 7-9, Cairo, Egypt.

11. Cobb, C. W., \& Douglas, P. H. (1928). A theory of production. The American Economic Review, 18(1), 139-195. Retrieved from the World Wide Web: http://www.institutodeestudiosurbanos.info/dmdocuments/cendocieu/ Especializacion_Mercados/Documentos_Cursos/Theory_Production-Cobb_Charles-1928.pdf

12. Coelli, T. (1996). A guide to DEAP version 2.1: A data envelopment analysis (computer) program (CEPA Working Paper 96/08, Centre for Efficiency and Productivity Analysis, University of New England, Australia).

13. Cook, W. D., \& Seiford, L. M. (2009). Data envelopment analysis (DEA)-Thirty years on. European Journal of Operational Research, 192(1), 1-17. https://doi.org/10.1016/j.ejor.2008.01.032

14. Das, A., \& Kumbhaker, S. (2012). Productivity and efficiency dynamic in Indian banking: An inputs distance function approach incorporation quality of inputs and outputs. Journal of Applied Economics, 27(2), 205-243. https://doi.org/10.1002/jae.1183

15. Farazi, S., Feyen, E., \& Rocha, R. (2011). Bank ownership and performance in the Middle East and North Africa region (Policy Research Working Paper No. WPS 5620, World Bank).

16. Färe, R., Grifell-Tatjé, E., Grosskopf, S., \& Knox Lovell, C. A. (1997). Biased technical change and the Malmquist productivity index. The Scandinavian Journal of Economics, 99(1), 119-127. https://doi.org/10.1111/14679442.00051

17. Färe, R., Grosskopf, S., Norris, M., \& Zhang, Z. (1994). Productivity growth, technical progress, and efficiency change in industrial countries. The American Economic Review, 84(1), 66-83. Retrieved from the World Wide Web: https://www.jstor.org/stable/2117971

18. Gattoufi, S., Sakr, S., \& Omran, M. (2008). Tracking the impact of mergers and acquisitions on the efficiency of commercial banks in MENA countries using a Malmquist index based approach. Paper presented at the ERF 15th Annual Conference, Nov. 23-25, Marriot Cairo Hotel, Cairo, Egypt.

19. Gattoufi, S., Sakr, S., \& Omran, M. (2009). Tracking the impact of change in ownership on the efficiency of commercial banks in MENA countries using a Malmquist index-based approach (Economic Research Forum, Working Paper Series No. 465).

20. Grifell-Tatjé, E., \& Lovell, C. A. K. (1997). The source of productivity change in Spanish banking. European Journal of Operational Research, 98(2), 364-380. https://doi.org/10.1016/S0377-2217(96)00353-0

21. Hassan, M. K., Sanchez, B., Ngene, G. M., \& Ashraf, A. (2012). Financial liberalisation and foreign bank entry on the domestic banking performance in MENA countries. African Development Review, 24(3), 195-207. https://doi.org/10.1111/j.1467-8268.2012.00318.x

22. Howcroft, B., \& Ataullah, A. (2006). Total factor productivity change: An examination of the commercial banking industry in India and Pakistan. The Service Industries Journal, 26(2), 189-202. https://doi.org/10.1080/02642060500369305

23. Isik, I., \& Hassan, M. K. (2003). Financial deregulation and total factor productivity change: an empirical study of Turkish commercial banks. Journal of Banking and Finance, 27(8), 1455-1485. https://doi.org/10.1016/S03784266(02)00288-1

24. Islam, M. M. (2003). Regulations and supervision of financial institutions in GCC countries. Managerial Finance, 29(7), 17-42. https://doi.org/10.1108/03074350310768328

25. Jaffry, S., Ghulam, Y., Pascoe, S., \& Cox, J. (2007). Regulatory changes and productivity of banking sector in the Indian sub-continent. Journal of Asian economics, 18(3), 415-438. https://doi.org/10.1016/j.asieco.2007.02.010

26. Kammoun, N., \& Ammar, A. (2012). The evolution of competition in banking in a transition economy: An empirical analysis if the Tunisian banking sector. International Journal of Business and Social Science, 3(13), 120-133. Retrieved from the World Wide Web: http://ijbssnet.com/journal/index/1369

27. Kobeissi, N. (2005). Impact of government, legal system and economic freedom on foreign investment in the MENA region. Journal of Comparative International Management, 8(1), 20-41. Retrieved from the World Wide Web: https://journals.lib.unb.ca/index.php/jcim/article/view/433/721 
28. Krishnasamy, G., Ridzwa, A. H., \& Perumal, V. (2003). Malaysian post-merger banks' productivity: Application of Malmquist productivity index. Managerial Finance, 30(4), 63-74. https://doi.org/10.1108/03074350410769038

29. Levcine, R. (1997). Financial development and economic growth: Views and agenda. Journal of Economic Literature, 35(2), 688-726. Retrieved from the World Wide Web: https://www.jstor.org/stable/2729790

30. Luo, X. (2003). Evaluating the profitability and marketability efficiency of large banks: An application of data envelopment analysis. Journal of Business Research, 56(8), 627-635. https://doi.org/10.1016/S01482963(01)00293-4

31. Mostafa, M. (2007). Modelling the efficiency of GCC banks: A data envelopment analysis approach. International Journal of Productivity and Performance Management, 56(7), 623-643. https://doi.org/10.1108/ 17410400710823651

32. Olson, D., \& Zoubi, T. A. (2011). Efficiency and bank profitability in MENA countries. Emerging Markets Review, 12(2), 94-110. https://doi.org/10.1016/j.ememar.2011.02.003

33. Poshakwale, S. S., \& Qian, B. (2011). Competitiveness and efficiency of the banking sector and economic growth in Egypt. African Development Review, 23(1), 99-120. https://doi.org/10.1111/j.1467-8268.2010.00275.x

34. Ramanathan, R. (2006). Evaluating the comparative performance of countries of the Middle East and North Africa: A DEA application. Socio-Economic Planning Sciences, 40(2), 156-167. https://doi.org/10.1016/ j.seps.2004.10.002

35. Rezitis, A. (2006). Productivity growth in the Greek banking industry: A non-parametric approach. Journal of Applied Economics, 9(1), 119-138. https://doi.org/10.1080/15140326.2006.12040641

36. Sathye, M. (2003). Efficiency of banks in a developing economy: The case of India. European Journal of Operational Research, 148(3), 662-671. https://doi.org/10.1016/S0377-2217(02)00471-X

37. Sufian, F., \& Habibullah, M. (2013). Banks' total factor productivity growth in a developing economy: Does globalisation matter? Journal of International Development, 26(6), 821-852. https://doi.org/10.1002/jid.2897

38. Tarawneh, M. (2006). A comparison of financial performance in the banking sector: Some evidence from Omani commercial banks. International Research Journal of Finance and Economics, 3(May), 101-113.

39. Turk-Ariss, R. (2009). Competitive behaviour in Middle East and North Africa banking systems. The Quarterly Review of Economics and Finance, 49(2), 693-710. https://doi.org/10.1016/j.qref.2008.03.002

40. Turk-Ariss, R. (2008). Financial liberalisation and bank efficiency: Evidence from post-war Lebanon. Applied Financial Economics, 18(11), 931-946. https://doi.org/10.1080/09603100701335408

41. Vassiloglou, M., \& Gioks, D. (1990). A study of relative efficiency of bank branches: an application of data envelopment analysis. The Journal of the Operational Research Society, 41(7), 591-597. https://doi.org/10.2307/2583436

42. Yildirim, H. S., \& Philippatos, G. C. (2002). Competition and contestability in Central and Eastern European banking markets (University of Tennessee, Working Paper). 